\title{
INCLUSIONS OF PLUTONIC MINERALS IN DIAMONDS FROM KIMBERLITE ROCKS OF THE NORTHERN EAST-EUROPEAN PLATFORM.
}

Zarharchenko O.D.; Kharkiv A.D.; Botova M.M.; Makhin A.I. and Pavlenko, T.A.

According to data of visual diagnosis it has been revealed, that diamonds with plutonic minerals inclusions from kimberlite pipes of the East-European platform(EEP) amount to 0,6 - $2 \%$ from the whole quantity of crystals.Inclusions of olivine and coesite are observed in diamonds of all pipes the most often; the quantity of inclusions of chrome-spinellid is also increased,garnets and pyroxenes occur more seldom.

The most minerals-inclusions are characteristic of a crystallographic cut as polyhedrons, that imparted them a ronded shape。

Inclusions have been analysed with $\mathrm{X}$-ray scanning spectral microanalyser "Kamebax-Microbeam",Camecal acceleration voltage $15 \mathrm{~kW}, 15 \mathrm{~mA}$ )。

Minerals of ultrabasic paragenesis. The composition of chromous gamet, chrome-spinellid, olivine,clinopyroxene and orthopyroxene have been studied.

Among five analysed grains of chromous garnet four grains belong to high-chromous knorringite-bearing variety, in which the content of $\mathrm{Cr}_{2} \mathrm{O}_{3}$ ranges from 10 to $13 \%, \mathrm{CaO}$-from 2,4 to 5,4\%, feruginousness of garnets is low and ranges from 11,9 to $15,3 \%$ 。 Besides recorded pyropes, garnet with low content of $\mathrm{Cr}_{2} \mathrm{O}_{3}-3 \%$ and $\mathrm{CaO}-2,9 \%$ and low ferruginousness $(f=12 \%$ ) has been established.

As for known chrome-spinellid - inclusions, once more analysed 14 grains are characteristic of low ferruginousness from 23 to 38 and of high chromousness from 83 to 90\%。Their content of $\mathrm{Cr}_{2} \mathrm{O}_{3}$ ranges from 64 to $90 \%$, moreover, in about half of chromites the amount of $\mathrm{Cr}_{2} \mathrm{O}_{3}$ is higher, than $67 \%$, that in inclusions of chromites from Yakutiya dianonds occurs very seldom and it is a regional typomorphic feature. The content of $\mathrm{TiO}_{2}$ in chromespinellids ranges from hundredth parts of percent to $0,26 \%$.

All five analysed olivine grains have similar composition and are characteristic of low ferruginousness of 6,6 to $7,9 \%$. 
Impurity of $\mathrm{Cr}_{2} \mathrm{O}_{3}$ was found in three olivine inclusions,moreover, in olivine, in its turn, was included in chrome-spinellid, the content of $\mathrm{Cr}_{2} \mathrm{O}_{3}$ is extremely high $-0,45 \%$. In two olivines the impurity of $\mathrm{NiO}$ is registered.

The aggregate of chrome-diopside and enstatite,found in one of diamonds,is of essential interest.Chrome-diopside is characteristic of increased magnrsia content CarCa+Mg $=43,2$, that in paragenesis with enstatite affirms high temperature of equilibrium。

Inclusion of chromous pyroxene, having emerald-green colour, is characteristic of increased content of $\mathrm{Cr}_{2} \mathrm{O}_{3}-7,8 \%$ semultaneously with anomalously high $\mathrm{Na}_{2} \mathrm{O}-5,9 \%$. Combination of chrome and sodium in clinopyroxenes leads to arising of rare component $\mathrm{NaCr}_{2} \mathrm{O}_{6}$ - ureyite, which in pure state occurs only in meteorites. The content $8 \%$ of $\mathrm{Cr}_{2} \mathrm{O}_{3}$ corresponds to $15 \%$ of ureyite component. Pyroxenes with such composition as inclusions in diamonds have not been fixed earlier.

Eclogitic paragenesis. From minerals of a given paragenesis garnet, clinopyroxene and coesite have been analysed.

Garnet ( 11 analyses) is represented by pyrope-almandine variety, which ferruginousness is 42 - 55\%. The content of Ca-component is 20 - 32\%, and in two samples value of Ca-component is particularly high -37 and 39\%, respectively. In two diamonds,together with orange-coloured garnets, colourless inclusions of coesite were distinguished and analysed.

The compositions of two omphacite inclusions are identical. Their content of jadeitic minal is high (about 50\%), impurity of $\mathrm{K}_{2} \mathrm{O}$ is $0,80 \%$. According to peculiarities of chernical composition they belong to the most rich in jadeite pyroxenes, known among inclusions in diamonds. Both by content of jadeite component and content of impurity $\mathrm{K}_{2} \mathrm{O}$, the studied pyroxenes approach pyroxenes from diamonds of Argail lamproitic pipe in the Western Australia.

Thus, the cited data show, that on a level with typomorphic features, common for a given complex of minerals of all regions, inclusions in diamonds of $\mathrm{EEP}$ are characterized by a series of reginal features. 